\title{
Acute respiratory infections, influenza-like illness and JIA: impact on disease activity and response to the influenza vaccine
}

\author{
Luciana M Carvalho ${ }^{2 *}$, Flávia E Paula ${ }^{2}$, Rodrigo VD Silvestre ${ }^{1}$, Luciana R Roberti ${ }^{2}$, Wyller A Mello ${ }^{1}$, Eurico Arruda ${ }^{2}$, \\ Virginia PL Ferriani ${ }^{2}$
}

From 2011 Pediatric Rheumatology Symposium sponsored by the American College of Rheumatology Miami, FL, USA. 2-5 June 2011

\section{Purpose}

To evaluate the frequency of ARI and IL in JIA patients and its impact on disease activity, and to assess immunogenicity, safety and effectiveness of Flu vaccine in JIA patients using immunosuppressive drugs, including antiTNF $\alpha$.

\section{Methods}

Surveillance for Flu and other respiratory virus: respiratory syncytial virus (RSV), metapneumovirus (MPV), parainfluenza virus (PIV), bocavirus (Bov), adenovirus (Adv), rhinovirus (RV) and coronavirus (Cov) was conducted in JIA patients attending a tertiary Pediatric Rheumatology Clinic from March to August 2007 (61 JIA patients included) and from March to August 2008 (63 JIA patients). Patients presenting signs of ARI and/ or IL had airway secretion collected in a $72 \mathrm{hs}$ period, by combined nasal and pharyngeal swab, and viruses detection was performed using real time PCR (qPCR). 44 JIA patients aged 2 to 18 years received trivalent split Flu vaccine A/Solomon Islands/3/2006, H1N1; A/Brisbane/ 10/200, H3N2; B/Florida/2006 (Sanofi Pasteur SA/ Butantan Institute) in 2008. Thirty-one of the patients (70\%) were on MTX or leflunomide and 5 (11\%) were on anti-TNF drugs at the time of vaccination. Clinical and laboratory evaluation, including ACRPed30 were performed during the surveillance period, before and after vaccination. Flu titers were determined by hemagglutination inhibition (HI) assay before and 30-40 days after vaccination. Immune response was defined by

${ }^{2}$ University of São Paulo Ribeirão Preto, Ribeirao Preto, Sao Paulo, Brazil Full list of author information is available at the end of the article seroconversion (a 4-fold or greater rise in $\mathrm{HI}$ antibodies) and seroprotection (HI titers at least 1:40).

\section{Results}

During the surveillance period, 105 ARI episodes were reported by the patients, and 28 of these episodes $(26,6 \%)$ were IL. Of 33 samples collected, $20(60 \%)$ were positive for at least one respiratory virus: Flu A 25\%, Flu B 5\%, RV 30\%, Adv 20\%, PIV 15\%, RSV 10\%, Bov 5\%, HCov $5 \%$. Virus co-infections were detected in $15 \%$ of the positive samples. During the same period, 49 JIA flares were observed and $8(16 \%)$ had a temporal relationship with ARI without any other plausible cause that may have triggered the events. Seroprotection rates after vaccination were higher than $70 \%$ (91-100\%) for all 3 Flu strains and seroconversion rates exceeded 40\% (7493\%). In general, response to Flu vaccine was not influenced by therapeutic regimens or disease activity, but patients using anti-TNF $\alpha$ drugs presented lower response to $\mathrm{H} 1 \mathrm{~N} 1$ strain. No significant differences were found in JIA activity index (ACRPed 30 ) after vaccination and no patient reported IL symptoms during the 6month post-vaccine period.

\section{Conclusion}

ARI are relatively frequent in JIA patients and can possibly have a role in JIA flares. Trivalent split FLU vaccine seems to be immunogenic, safe and effective in JIA patients using immunosuppressive agents and should be given to all children with JIA.

\section{Disclosure}

Luciana M. Carvalho: None; Flávia E. Paula: None; Rodrigo V.D. Silvestre: None; Luciana R. Roberti: None; 
Wyller A. Mello: None; Eurico Arruda: None; Virginia P.L. Ferriani: None.

\section{Author details}

${ }^{1}$ Evandro Chagas Institute (WHO National Influenza Center), Ananindeua, Para, Brazil. ${ }^{2}$ University of São Paulo Ribeirão Preto, Ribeirao Preto, Sao Paulo, Brazil.

Published: 13 July 2012

doi:10.1186/1546-0096-10-S1-A103

Cite this article as: Carvalho et al: Acute respiratory infections,

influenza-like illness and JIA: impact on disease activity and response to the influenza vaccine. Pediatric Rheumatology 2012 10(Suppl 1):A103.

Submit your next manuscript to BioMed Central and take full advantage of:

- Convenient online submission

- Thorough peer review

- No space constraints or color figure charges

- Immediate publication on acceptance

- Inclusion in PubMed, CAS, Scopus and Google Scholar

- Research which is freely available for redistribution

Submit your manuscript at www.biomedcentral.com/submit 